also contained kanamycin resistance for the selection of transformants. The coat protein was inserted under control of a $C a M V 35 S$ promoter in an anti-sense orientation. Putative transformants were selected for four months on media containing $25 \mu \mathrm{g} / \mathrm{mL}$ Geneticin Disulfate (G418). The objective of the present study is to further investigate and characterize the putative transgenic lines, which have been selected for antibiotic resistance. Molecular characterization of transformants is ongoing. Micropropagation is being carried out to multiply the transformed plant material. Plantlets will be used to develop an in vitro inoculation assay to test the resistance to CyMV. Future work will investigate the resistance of these lines to the Cymbidium mosaic virus.

\title{
Pestiferous scale insects on native epiphytic orchids in south Florida: a new threat posed by exotic species
}

\footnotetext{
LaWrence W. ZetTler ${ }^{1 *}$, JenNifer A. ZetTler ${ }^{2}$, Larry W. Richardson ${ }^{3}$, Haleigh A. Ray ${ }^{1,4}$, John P. McCormick ${ }^{1,5}$, Andrew L. Stice ${ }^{1} \&$ Ian Stocks ${ }^{6}$

${ }^{1}$ Department of Biology, Illinois College, 1101 West College Ave., Jacksonville, IL 62650, USA

${ }^{2}$ Department of Biology, Armstrong Atlantic State University, 11935 Abercorn St., Savannah, GA 31419, USA

${ }^{3}$ Florida Panther NWR, U.S. Fish \& Wildlife Service, 3860 Tollgate Blvd., Naples, FL 34114, USA

${ }^{4}$ Current address: Department of Entomology and Nematology, University of Florida, Gainesville, FL 32611, USA

${ }^{5}$ Current address: Department of Biological Sciences, East Tennessee State University, Johnson City, TN 37614, USA

${ }^{6}$ Division of Plant Industry, Florida Department of Agriculture \& Consumer Services, Gainesville, FL 32614, USA

*Author for correspondence: 1wzettle@mail.ic.edu

In 2009, phytophagous insects (Hemiptera: Coccidae, Pseudococcidae) were collected from the inflorescences of the ghost orchid, Dendrophylax lindenii, at an isolated natural site in Collier Co., Florida, surrounded by an urban area. During the next two years, additional surveys were carried out in more remote orchid-rich habitats to determine if, and to what extent, other native epiphytic orchids were infested. Within the Florida Panther National Wildlife Refuge in 2010, 29 of 46 orchids sampled at one site (Cochran Lake) harbored three species of exotic scales: orchid pit scale (Asterolecanium epidendri Asterolecaniidae), brown soft scale (Coccus hesperidum, Coccidae), and boisduval scale (Diaspis boisduvalii, Diaspididae). Heaviest infestations were noted on Epidendrum amphistomum, E. nocturnum, E. rigidum, and Prosthechea cochleata.

The follow-up study the second year (2011) was then expanded to include Fakahatchee Strand State Preserve. A total of 1,726 orchids spanning 10 taxa were surveyed at seven locations. Boisduval scale was detected on $2.3 \%$ of the orchids from six of the ten orchid species in both the Florida Panther NWR and Fakahatchee Strand. Prosthechea cochleata and E. amphistomum appeared to be most vulnerable to this scale, with infection totals of $5.8 \%$ and $2.1 \%$, respectively. Of 44 scales collected from the 39 orchids, $27 \%$ hosted hymenopteran parasitoids in various stages of development. The presence of $D$. boisduvalii adds an additional burden to state-endangered orchid populations and indicates that resource managers may need to expand management approaches to include plant-parasitic insect control.
} 